\title{
The Impact of Business Intelligence on Strategic Performance in Commercial Banks Operating in the Sate of Kuwait
}

\author{
Dr. Hamad Salem Al-Merri ${ }^{1}$ \\ ${ }^{1}$ Ministry of Health Department of international Health Relations, Kuwait \\ Correspondence: Dr.Hamad Salem Al-Merri, Ministry of Health Department of international Health Relations , \\ Kuwait
}

Received: February 13, 2020

Accepted: June 29, $2020 \quad$ Online Published: July 21, 2020

doi:10.5539/ibr.v13n8p91

URL: https://doi.org/10.5539/ibr.v13n8p91

\begin{abstract}
This study aimed to identify the impact of business intelligence on strategic performance in commercial banks operating in the State of Kuwait the researcher used the descriptive analytical approach to introduce both business intelligence and strategic performance. The study population consisted of employees working in top and middle management in commercial banks operating in State of Kuwait. Stratified random sample amounting 363 subjects was used. 270 questionnaires were collected representing $74.3 \%$ of the total sample.

The study concluded that business intelligence system ensures data processing using data storage techniques and data extraction to obtain consistent and qualified information, thus providing the required knowledge to achieve the strategic goals and objectives by end users and executives in the future. The researcher recommends that Kuwaiti banks should keep pace with developments in the field of business intelligence to be employed in a better way in enhancing its strategic performance, in addition to conduct future studies that follow the analytical approach to deepen its utilization in Kuwaiti commercial banking sector.
\end{abstract}

Keywords: business intelligence, performance, strategic performance, commercial banks

\section{Introduction}

Information and communication technologies have changed the way most industries and institutions have used in dealing with companies to meet their customers increasing demands. Recently, banking industry is one of the main businesses that have been greatly affected by technology, since operations have been advanced from mere exchange of cash, checks and other negotiable methods to application of information technology (IT) in dealing with business in banking industry.

The concept of business intelligence is widely used to help organizations' decision-making bodies manage data and make realistic decisions. This is because of its capabilities to mitigate risk and increase certainty in the midst of latest global economic disturbances, and this in its turn is applied to banking sector.

The researchers worked to show the strategic performance since it is necessary to define and use banks strategic capabilities. Strategic performance can be evaluated by many bank departments according to its work conditions, which leads to many different interpretations of "successful performance". It can also be said that each of strategic performance perspectives may be unique. Moreover, each bank has a unique set of circumstances, which makes measuring performance a difficult process sometimes .

Within this approach, many banks have tried to use many methods to achieve their strategic success as a result of great technological progress and technical practices in order to achieve strategic success at industry and market level together. Among these methods the use of business intelligence by focusing on business intelligence technology dissemination, culture of business intelligence and finding practiced structure among the various departments and divisions of business intelligence in the bank, so that this method is a tool that helps in achieving strategic success at the bank, market and industry levels. And given that business intelligence is a new business-driven phenomenon that can add value to institutions. It is an umbrella for systems and procedures by which raw data is converted into useful information for managers to make better decisions. So this study aims to highlight the impact of business intelligence on strategic performance in Commercial banks operating in the State of Kuwait. 


\section{Problem Statement}

The study problem arises in light of great variation in strategic performance level between Kuwaiti commercial banks, which may be due to intensive competition with foreign banks and the variation in financial and credit capabilities between different banks. This makes it necessary to highlight the importance of information provided by business intelligence that enhances the competitiveness of commercial banks in the State of Kuwait. In light of lack of previous studies that deal with this topic, this theoretical study aims to answer the following main question:

What is the Impact of Business Intelligence on Strategic Performance in Commercial Banks operating in the Sate of Kuwait?

\section{The Study Importance}

\section{- Scientific Importance:}

This study is an important scientific addition in the field of business intelligence research and studies and its link to strategic performance.

\section{- Practical importance:}

The recommendations of this study will contribute to establish a foundation for future studies that use descriptive analytical approach to deepen the benefit of this issue in Kuwaiti commercial banking sector.

\section{Study Objectives}

This study seeks to achieve the following goals:

- To clarify the concept of business intelligence.

- To explain the concept of strategic performance

- To study the impact of business intelligence on strategic performance in commercial banks operating in the State of Kuwait

\section{Study Hypotheses}

\section{Main hypothesis}

Ho: There is no statistically significant impact at significance level $(\alpha \leq 0.05)$ of business intelligence on strategic performance in commercial banks operating in the State of Kuwait.

\section{The following sub-hypotheses are derived:}

H01: There is no statistically significant impact at significant level $(\alpha \leq 0.05)$ of business intelligence on financial dimension of strategic performance in commercial banks operating in the State of Kuwait.

H02: There is no statistically significant impact at significant level $(\alpha \leq 0.05)$ of business intelligence on customer dimension of strategic performance in commercial banks operating in the State of Kuwait

H03 There is no statistically significant impact at significant level $(\alpha \leq 0.05)$ of business intelligence on internal operation dimension of strategic performance in commercial banks operating in the State of Kuwait:

H04: There is no statistically significant impact at significant level $(\alpha \leq 0.05)$ of business intelligence on learning and growth dimension of strategic performance in commercial banks operating in the State of Kuwait

\section{Study methodology:}

The researcher used the descriptive analytical approach to achieve study goals, as well as the method of quantitative data collection in order to test the impact of business intelligence on strategic performance, as this approach is appropriate to the nature of the study and appropriate for achieving its goals

\section{Study population}

The study population consisted of employees who are working in top and middle management in commercial banks operating in the State of Kuwait, amounting 6462 administrative individual .Stratified random sample consisted of 363 subjects was selected from employees working in top and middle management in commercial banks operating in the State of Kuwait (Al-Najjar, Al-Najjar, and Al-Zoubi, 2013, 109) .270 questionnaires were collected, representing $74.3 \%$ of the total sample.

\section{Data collection:}

This study used two methods of data collection: 
-Secondary sources: The researcher reviewed number of previous studies related to the current study by visiting university libraries and databases in digital libraries, in addition to the Internet, annual reports and yearly newsletters that are related to study topic and its variables.

-Primary Sources: The researcher has developed a questionnaire that measures study variables to include a set of questions through which information can be collected from study sample.

\section{Study instrument Validity and Reliability}

The researcher displayed the study questionnaire to a group of universities staff from Jordan and the State of Kuwait, in order to express an opinion regarding questionnaire paragraphs and extent of their clarity, and coherence.

As for tool reliability, the researcher used the Cronbach Alpha in order to verify the study reliability. The alpha value $=0.883$, which is an excellent ratio, being higher than the acceptable percentage 0.60 (Guajarati, 2004)

\section{Theoretical Framework}

\section{Business intelligence}

Many companies and organizations today still depend on historical data analytics and reporting tools to carry out their key operations. Despite the rapid gains in business intelligence systems s and decision support systems. Most companies and organizations continue to depend on old systems. These systems are usually not integrated with other systems and sometimes do not have predictive and analytical capabilities. According to (Rahman (2011) studies indicate that less than twenty percent (20\%) of any specific analytical applications are frequently used within a workflow viewpoint. Business intelligence refers to a set of tools and techniques that help in transforming large amount of data from different sources to meaningful information to support decision-making and improve organizational performance.

Business intelligence tools have emerged in the past decade as a major driving force for enhancing organizational performance (Ramakrishnan et al., 2012)...Business intelligence also means collecting data from each of Internal and external data resources, in addition to store, and analyze it to make it more reliable To help make better decisions (Negash, 2004), the demand for business intelligence applications continues to grow even while the demand for most IT products is weak, therefore industries such as banking industry that have approved the use of computer-based systems apply intelligence works in their activities to make them more efficient and effective. (Azvine, Cui \& Nauck, 2005).

Business intelligence technologies and tools are relatively considered new concepts, and they have contributed to the design of the work of many organizations due to their ability to benefit from large amounts of data through improved analysis, reporting and improved inquiry. The technologies and programs features are classified into three main categories, such as: - Predictive Modeling Tools (which are usually used to analyze potential future scenarios). - Reporting and trend analysis (used for both historical and emerging). - Analyzing customer behavior. According to it, business intelligence requires three major classes of technology, such as data storages, analytical tools, and reports preparing tools. Where business intelligence accomplishes decision-making tasks in institutions through the use of methods of data extraction and storage and online analytical processing (OLAP). (Azvine, et al., 2005)

To improve the bank's strategic orientation and competitiveness, managers need to use some specific tools to support their decisions throughout decision-making process. Business intelligence can be useful by providing special results to enhance decision-making capabilities from different point of view (Isik et al., 2013) . These tools cover a wide range of technologies used to collect, provide, access and analyze data from various sources to assist bank managers to make more effective management decisions (Cheung and $\mathrm{Li}, 2011$; Delen and Demirkan, 2013).

Moreover, the strategic use of business intelligence in the bank has been classified in three important areas as follows: performance management, business activity monitoring, and reports preparing (Negash, 2004). Likewise, Petrini and Pozzebon (2009) grouped business intelligence functions into three core categories including analysis (data extraction), monitoring (information boards, performance sheets, and alarm systems) and reports preparing

\section{Strategic Performance}

Strategic performance represents the competitive organization that adopts specific competition strategy striving to achieve the best strategic performance in the sector in which it operates (Abdallah et al., 2009)

There are two ways to deal with performance: financial, "sales-based," and non-financial, or "company-based". 
While finances are measured by dimensions such as profitability, growth, productivity, level of sales revenue, market share, product, return on investment, and product value added. Non-financial are measured through employee development, customer satisfaction, job satisfaction and effective internal organizational processes (Eniola \& Ektebang, 2014). Measuring performance is therefore necessary because it is a way to determine whether an organization is achieving its goals (Makanga \& Paul, 2017).

Kaplan \& Norton (1992) outlined four main areas represented in the financial field, customers, internal operations, learning and growth. Organizations can focus on, and these areas include a variety of goals, measures, goals, and initiatives. From this standpoint, these indicators provide a comprehensive and clear picture of the organizations' performance through the following four perspectives:

1-Financial: The financial perspective takes into account the final outcome or economic outcomes resulting from activities that were previously accomplished by organization. It focuses on measures related to profitability through which shareholders can verify the profitability of their investments, as the following question arises: How to succeed financially should we appear in front of shareholders? It is worth noting that financial measures represent the traditional method of analyzing organizational success. As for organizations in which tangible assets constitute a large part of their market value, these measures are appropriate to measure the performance of this type of organization. Kaplan \& Atkinson believe that these measures reflect comprehensive financial performance, as well as the ability to predict organization's ability to pay off its debt in the long run

2-The customers through which organization can be viewed is represented by customers. Therefore, adopting this perspective requires identifying customers and market sectors in which organization can compete, and then the means that are used to provide customers and markets with value. So, there is a need to find specific scales that help in answering the following question: In order to achieve our vision, how should we appear in the eyes of our customers? Accordingly, the choice of this type of scales depends mainly on the type of customer and the target value that organization seeks to provide to this customer.

3-Internal Operations: This perspective focuses on identifying the operations needed to accomplish the goals that were included in the previous two perspectives. From this standpoint, it is necessary for the organizations administration to answer the following question: In order to achieve the satisfaction of customers and shareholders, what are the operations and activities that we should be distinguished with? The goal of internal operations perspective is materialized in defining the basic processes necessary to equip customers with products or services that they desire, and then developing scales that help in ensuring that these operations are performed well, as they help managers to focus on important internal processes that ultimately enable them to meet customer expectations. According to Kaplan \& Norton (1992), the focus on critical internal operations enables organizations to deliver the proposed value to customers in the targeted market sectors and to meet shareholders expectations in achieving high financial returns

4-Learning and growth: It focuses on what is required for achieving objectives of the previous three perspectives. Under this perspective, the organization's management is required to answer the following question: In order to achieve our vision, how can we sustain our capabilities through change and improvement? Thus, the main focus of the aforementioned perspective is to ensure that organization can develop its own capabilities in a way that enables it to accomplish important activities and events. Accordingly, it is assumed that the learning and growth perspective directs the other three perspectives in the right direction, and in a way that supports the overall orientation of the organization.

From the foregoing it is clear that the previous four perspectives are as an approach to measure strategic performance that was designed to combine financial and non-financial measures related to main success factors in organization's strategy. It helps organizations managers to balance between short-term performance measures and long-term goals that are linked with vision, mission and core values needed to implement strategies at business and organizational unit's level. So it represents a system of management rather than a system of measurement

\section{Statistical Analysis}

\section{Study sample description:}

Frequencies and percent have been extracted for study sample description. Researcher found that the largest percent of the study sample $(60 \%)$ are males. It was found that $64.1 \%$ of the sample have bachelor's degree, and it also showed that high percent are youth, $49.6 \%$ of the sample their ages ranged between 30 - less than 40 years, and it was found that $47.4 \%$ of the sample had experience ranging between 15 - less than 25 years. 


\section{Descriptive statistics:}

Means and standard deviations have been calculated to describe the sample responses towards the following resolution paragraphs:

Table 1. Means and standard deviations of sample's responses regarding Business Intelligence

\begin{tabular}{|c|c|c|}
\hline Question & Mean & S.D. \\
\hline 1. The bank management attracts distinguished competencies in banking & 4.26 & .560 \\
\hline $\begin{array}{l}\text { 2. The administration is keen to collect all the data necessary for banking } \\
\text { operations }\end{array}$ & 4.32 & .521 \\
\hline 3. The bank's internal systems are developed periodically & 4.25 & .520 \\
\hline 4. The administration is interested in reading the work environment accurately & 4.46 & .643 \\
\hline $\begin{array}{l}\text { 5. The administration is keen to provide modern banking systems that increase } \\
\text { work efficiency }\end{array}$ & 4.34 & .592 \\
\hline 6. Customer data is kept confidential & 4.40 & .527 \\
\hline 7. All available information is analyzed before making a decision. & 4.20 & .686 \\
\hline $\begin{array}{l}\text { 8. Risks sources of the to which the bank is exposed are monitored to avoid their } \\
\text { occurrence }\end{array}$ & 4.30 & .681 \\
\hline 9. Attention is paid to updating the bank's intranet & 4.35 & .583 \\
\hline 10. An advanced electronic archiving system is followed at the bank & 4.33 & .571 \\
\hline General Mean & 4.32 & .329 \\
\hline
\end{tabular}

Table 1 shows means of sample subjects' responses on statements that measure the Business Intelligence. It was found that there are positive attitudes toward above statements because their means are greater than mean of the scale.

Table 2. Means and standard deviations of sample's responses regarding Strategic Performance

\begin{tabular}{|c|c|c|}
\hline Question & Mean & S.D. \\
\hline There is a continuous improvement in the financial performance of the bank & 4.40 & .505 \\
\hline There is an improvement in the services that increase the profitability of the bank & 4.44 & .554 \\
\hline $\begin{array}{l}\text { 3. There is an improvement in services that increase the return on investment of the } \\
\text { bank }\end{array}$ & 4.56 & .560 \\
\hline 4. There is an interest in improving the level of operational efficiency of the bank & 4.45 & .527 \\
\hline $\begin{array}{l}\text { 5. The bank's management is keen to increase its share in the targeted banking } \\
\text { market }\end{array}$ & 4.46 & .521 \\
\hline 6. The bank adopts different policies to attract new customers to the bank & 4.52 & .529 \\
\hline The Bank is keen to maintain its existing customers & 4.44 & .554 \\
\hline $\begin{array}{l}\text { 8. The bank is keen to encourage its customers to increase their profits by increasing } \\
\text { the size of their deposits with }\end{array}$ & 4.40 & .547 \\
\hline 9. There is an interest in handling customer feedback and complaints & 4.28 & .566 \\
\hline 10. The focus is on diversification of banking services provided to customers & 4.29 & .549 \\
\hline 11. There is interest in developing the bank's internal operations & 4.23 & .573 \\
\hline $\begin{array}{l}\text { 12. There is compliance with all standards and procedures established by the Central } \\
\text { Bank }\end{array}$ & 4.40 & .630 \\
\hline 13. The services provided to customers are characterized by a high level of quality & 4.27 & .581 \\
\hline 14. There is an interest in developing various services provided to clients & 4.34 & .568 \\
\hline $\begin{array}{l}\text { 15. The services provided in the bank are distinguished from the services provided by } \\
\text { the competing banks }\end{array}$ & 4.22 & .599 \\
\hline 16. There is an interest in training bank employees periodically & 4.25 & .600 \\
\hline 17. Employees are encouraged to be creative at work & 4.33 & .577 \\
\hline $\begin{array}{l}\text { 18. Special policies are adopted to motivate employees to raise their level of } \\
\text { performance in the bank }\end{array}$ & 4.34 & .665 \\
\hline 19. The employee's promotion is linked to the efficiency of his work & 4.21 & .602 \\
\hline 20. The bank's management is keen to keep its qualified employees & 4.19 & .616 \\
\hline General Mean & 4.35 & .290 \\
\hline
\end{tabular}

Table 2 shows means of sample subjects' responses on statements that measure the Strategic Performance. It is found that there are positive attitudes toward above statements because their means are greater than mean of the scale. 


\section{Hypothesis Testing}

Main hypothesis

Ho: There is no statistically significant impact at significance level $(\alpha \leq 0.05)$ of business intelligence on strategic performance in commercial banks operating in the State of Kuwait.

Table 3. Ho test

\section{Model Summary}

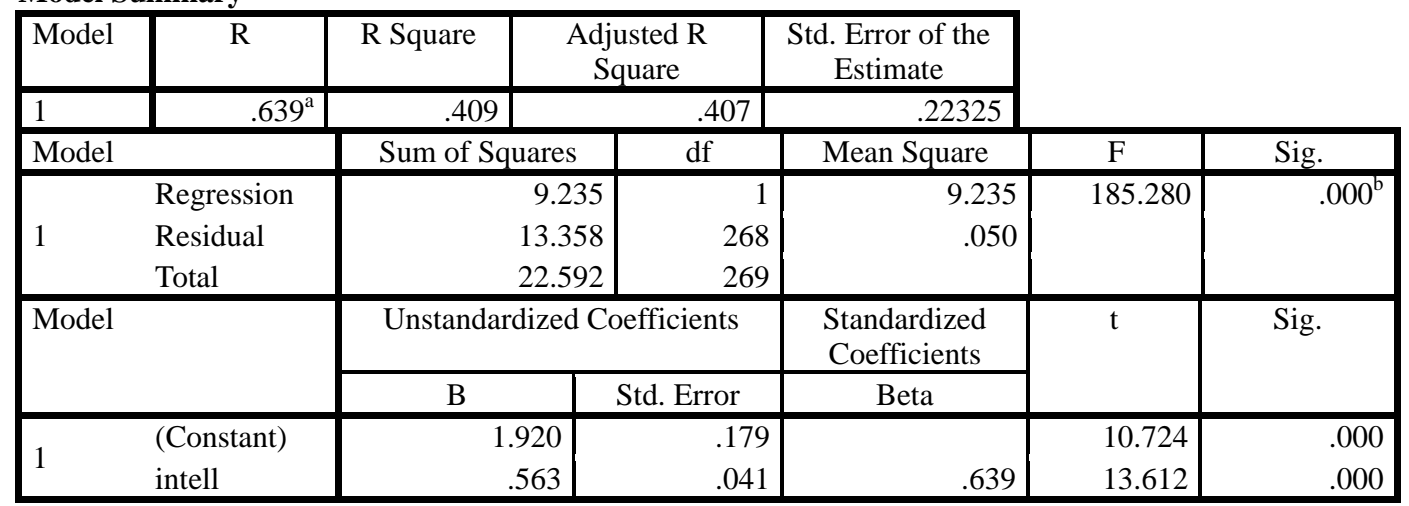

Simple regression test was used to test the above hypothesis. $T$ value $=13.612$ which is statistically significant at level $0.05, \mathrm{R}$ value $=0.639$ reflects the strength of the relationship between the independent variable and the dependent variable, and therefore it can be concluded that there is a statistically significant impact at significance level $(\alpha \leq 0.05)$ for business intelligence in strategic performance in commercial banks operating in the State of Kuwait

From this hypothesis, the following sub-hypotheses are derived:

H01: There is no statistically significant Impact at significance level $(\alpha \leq 0.05)$ of business intelligence on the financial dimension of strategic performance in commercial banks operating in the State of Kuwait.

Table 4. Ho1 test

Model Summary

\begin{tabular}{|c|c|c|c|c|c|c|c|}
\hline Model & $\mathrm{R}$ & R Square & \multicolumn{2}{|c|}{$\begin{array}{l}\text { Adjusted R } \\
\text { Square }\end{array}$} & $\begin{array}{l}\text { Std. Error of the } \\
\text { Estimate }\end{array}$ & & \\
\hline 1 & $.714^{\mathrm{a}}$ & .509 & & .507 & .21562 & & \\
\hline \multicolumn{2}{|l|}{ Model } & \multicolumn{2}{|c|}{ Sum of Squares } & df & Mean Square & $\mathrm{F}$ & Sig. \\
\hline 1 & $\begin{array}{l}\text { Regression } \\
\text { Residual } \\
\text { Total }\end{array}$ & & $\begin{array}{l}12.930 \\
12.459 \\
25.390 \\
\end{array}$ & $\begin{array}{r}1 \\
268 \\
269 \\
\end{array}$ & $\begin{array}{r}12.930 \\
.046\end{array}$ & 278.131 & $.000^{\mathrm{b}}$ \\
\hline \multirow[t]{2}{*}{ Model } & & \multicolumn{3}{|c|}{ Unstandardized Coefficients } & $\begin{array}{c}\text { Standardized } \\
\text { Coefficients }\end{array}$ & $\mathrm{t}$ & Sig. \\
\hline & & $\mathrm{B}$ & & Std. Error & Beta & & \\
\hline 1 & $\begin{array}{l}\text { (Constant) } \\
\text { intell }\end{array}$ & & $\begin{array}{l}487 \\
666\end{array}$ & $\begin{array}{l}.173 \\
.040 \\
\end{array}$ & .714 & $\begin{array}{r}8.597 \\
16.677 \\
\end{array}$ & $\begin{array}{l}.000 \\
.000 \\
\end{array}$ \\
\hline
\end{tabular}

a. Dependent Variable: finance

Simple regression test was used to test the above hypothesis. $\mathrm{T}$ value $=16.677$ which is statistically significant at level $0.05, \mathrm{R}$ value $=0.714$ reflects the strength of the relationship between the independent variable and the dependent variable, and therefore it can be concluded that there is a statistically significant impact at significance level $(\alpha \leq 0.05)$ for business intelligence in financial dimension for strategic performance in commercial banks operating in the State of Kuwait 
H02: There is no statistically significant impact at significant level $(\alpha \leq 0.05)$ of business intelligence on customer dimension of strategic performance in commercial banks operating in the State of Kuwait

Table 5 .Ho2 test

Model Summary

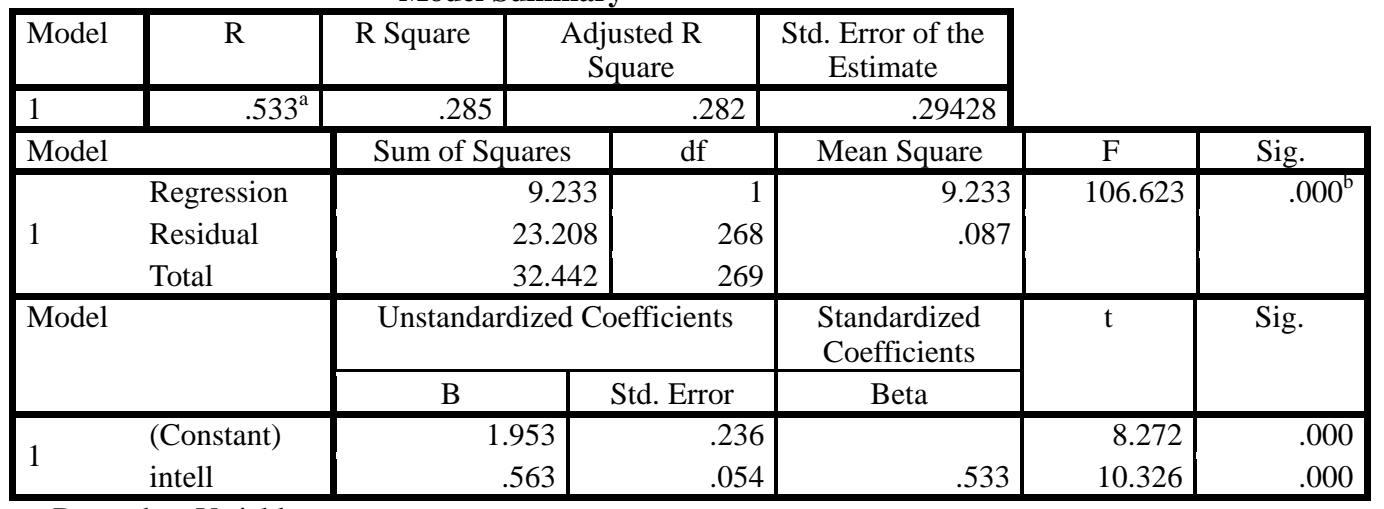

a. Dependent Variable: customer

Simple regression test was used to test the above hypothesis. $T$ value $=10.326$ which is statistically significant at level $0.05, \mathrm{R}$ value $=0.533$ reflects the strength of the relationship between the independent variable and the dependent variable, and therefore it can be concluded that there is a statistically significant impact at significance level $(\alpha \leq 0.05)$ for business intelligence in customers dimension for strategic performance in commercial banks operating in the State of Kuwait

H03 There is no statistically significant impact at significant level $(\alpha \leq 0.05)$ of business intelligence on internal operation dimension of strategic performance in commercial banks operating in the State of Kuwait:

Table 6. Ho3 test

Model Summary

\begin{tabular}{|c|c|c|c|c|c|c|c|}
\hline Model & $\mathrm{R}$ & R Square & \multicolumn{2}{|c|}{$\begin{array}{l}\text { Adjusted R } \\
\text { Square }\end{array}$} & $\begin{array}{l}\text { Std. Error of the } \\
\text { Estimate }\end{array}$ & & \\
\hline 1 & $.484^{\mathrm{a}}$ & .234 & & .231 & .32803 & & \\
\hline \multicolumn{2}{|l|}{ Model } & \multicolumn{2}{|c|}{ Sum of Squares } & Df & Mean Square & $\mathrm{F}$ & Sig. \\
\hline 1 & $\begin{array}{l}\text { Regression } \\
\text { Residual } \\
\text { Total }\end{array}$ & & $\begin{array}{r}8.807 \\
28.838 \\
37.645 \\
\end{array}$ & $\begin{array}{r}1 \\
268 \\
269 \\
\end{array}$ & $\begin{array}{r}8.807 \\
.108\end{array}$ & 81.851 & $.000^{\mathrm{b}}$ \\
\hline \multirow[t]{2}{*}{ Model } & & \multicolumn{3}{|c|}{ Unstandardized Coefficients } & $\begin{array}{c}\text { Standardized } \\
\text { Coefficients }\end{array}$ & $\mathrm{t}$ & Sig. \\
\hline & & $\mathrm{B}$ & & Std. Error & Beta & & \\
\hline 1 & $\begin{array}{l}\text { (Constant) } \\
\text { intell }\end{array}$ & & $\begin{array}{l}919 \\
549\end{array}$ & $\begin{array}{l}.263 \\
.061\end{array}$ & .484 & $\begin{array}{l}7.293 \\
9.047\end{array}$ & $\begin{array}{l}.000 \\
.000\end{array}$ \\
\hline
\end{tabular}

a. Dependent Variable: process

Simple regression test was used to test the above hypothesis. $\mathrm{T}$ value $=9.047$ which is statistically significant at level $0.05, \mathrm{R}$ value $=0.484$ reflects the strength of the relationship between the independent variable and the dependent variable, and therefore it can be concluded that there is a statistically significant impact at significance level $(\alpha \leq 0.05)$ for business intelligence in internal operations dimension for strategic performance in commercial banks operating in the State of Kuwait 
H04: There is no statistically significant impact at significant level $(\alpha \leq 0.05)$ of business intelligence on learning and growth dimension of strategic performance in commercial banks operating in the State of Kuwait

Table 7. Ho4 test

Model Summary

\begin{tabular}{|c|c|c|c|c|c|c|c|}
\hline Model & $\mathrm{R}$ & R Square & \multicolumn{2}{|c|}{$\begin{array}{c}\text { Adjusted R } \\
\text { Square }\end{array}$} & $\begin{array}{l}\text { Std. Error of the } \\
\text { Estimate }\end{array}$ & & \\
\hline 1 & $.521^{\mathrm{a}}$ & .272 & & .269 & .36030 & & \\
\hline \multicolumn{2}{|l|}{ Model } & \multicolumn{2}{|c|}{ Sum of Squares } & $\mathrm{df}$ & Mean Square & $\mathrm{F}$ & Sig. \\
\hline \multirow{3}{*}{1} & Regression & \multicolumn{2}{|r|}{12.97} & 1 & \multirow{3}{*}{$\begin{array}{r}12.970 \\
.130\end{array}$} & \multirow[t]{3}{*}{99.910} & \multirow[t]{3}{*}{$.000^{\mathrm{b}}$} \\
\hline & Residual & \multirow{2}{*}{\multicolumn{2}{|c|}{34.790}} & 268 & & & \\
\hline & Total & & & 269 & & & \\
\hline \multirow[t]{2}{*}{ Model } & & \multicolumn{3}{|c|}{ Unstandardized Coefficients } & Standardized & \multirow[t]{2}{*}{$\mathrm{t}$} & \multirow[t]{2}{*}{ Sig. } \\
\hline & & $\mathrm{B}$ & & Std. Error & Beta & & \\
\hline \multirow{2}{*}{1} & (Constant) & & 386 & .289 & & 4.796 & .000 \\
\hline & intell & & 667 & .067 & .521 & 9.996 & .000 \\
\hline
\end{tabular}

a. Dependent Variable: growth

Simple regression test was used to test the above hypothesis. $\mathrm{T}$ value $=9.996$ which is statistically significant at level $0.05, \mathrm{R}$ value $=0.521$ reflects the strength of the relationship between the independent variable and the dependent variable, and therefore it can be concluded that there is a statistically significant impact at significance level $(\alpha \leq 0.05)$ for business intelligence in learning and growth dimension for strategic performance in commercial banks operating in the State of Kuwait

\section{Conclusions and Recommendations}

This study provides a conceptual framework for the impact of business intelligence on strategic performance, as it indicates some benefits of business intelligence, the most prominent of which is the analysis of all data to obtain information in their database management systems, to organize the routine process quickly, to reduce its costs, and to increase the return on investment on the long term, and this will be reflected in the strategic performance.

The business intelligence system also ensures data processing using data storage and data mining techniques to obtain consistent and qualified information, thus providing the necessary knowledge to achieve strategic goals and objectives by end users and executives in the future. In addition, the development of information technology that is an important infrastructure for the business intelligence system provides opportunities and provides a competitive capacity for the bank in the banking market.

Consequently, the researcher recommends Kuwaiti banks to keep up with the developments in the field of business intelligence in order to employee it in better form to enhance their strategic performance, in addition to conducting future studies that follow the analytical approach to deepen their utilization in the Kuwaiti commercial banking sector.

\section{References}

Abdallah, A. B., Pham, A. C., \& Matsui, Y. (2009). Investigating the relationship between strategic manufacturing goals and mass customization. The 16th International Annual European Operations Management Association (EurOMA) Proceedings, Goteborg, June, pp. 1-10.

Al-Najjar, F., Al-Najjar, N., \& Al-Zoubi, M. (2013). Scientific Research Methods: An Applied Perspective. Jordan, Amman: Dar Al-Hamid for Publishing and Distribution.

Azvine, B., Cui, Z., \& Nauck, D. (2005). Towards real-time business intelligence. BT Technology Journal, 23, 214-225. https://doi.org/10.1007/s10550-005-0043-0

Cheung, C., \& Li, F. (2011). A quantitative correlation coefficient mining method for business intelligence in small and medium enterprises of trading business. Expert Systems with Applications, 39(7), 6279-6291. https://doi.org/10.1016/j.eswa.2011.10.021

Delen, D., \& Demirkan, H. (2013). Data, information and analytics as services. Decision Support Systems, 55(1), 
359-363. https://doi.org/10.1016/j.dss.2012.05.044

Eniola, A. A., \& Ektebang, H. (2014). SME firms performance in Nigeria: Competitive advantage and its impact. International Journal of Research Studies in Management, 3(2), 75-86. https://doi.org/10.5861/ijrsm.2014.854

Gujarati, D.N. (2004) Basic Econometrics. 4th Edition, McGraw-Hill Companies

Isik, Ö., Jones, M. C., \& Sidorova, A. (2013). Business intelligence success: the roles of BI capabilities and decision environments. Information \& Management, 50(1), 13-23. https://doi.org/10.1016/j.im.2012.12.001

Kaplan, R. S., \& Norton, D. P. (1992). The balanced scorecard: measures that drive performance. Harvard Business Review, 70(1), 71-79.

Makanga, R. O., \& Paul, S. N. (2017). Influence of strategic management practices on performance of Kenya power and lighting company ltd, Nairobi County, Kenya. The Strategic Journal of Business \& Change Management, 4(4), 289-306.

Negash, S. (2004). Business intelligence. Communications of the Association for Information Systems, 13(1), 177-195. https://doi.org/10.17705/1CAIS.01315

Petrini, M., \& Pozzebon, M. (2009). Managing sustainability with the support of business intelligence: integrating socio-environmental indicators and organisational context. The Journal of Strategic Information Systems, 18(4), 178-191. https://doi.org/10.1016/j.jsis.2009.06.001

Rahman, S. (2011). The impact of adopting Business Intelligence (BI) in organizations. Master thesis, University of Appsala. Sweden.

Ramakrishnan, T., Khuntia, J., Kathuria, A., \& Saldanha, T. (2016). Business Intelligence Capabilities and Effectiveness: An Integrative Model. 49th Hawaii International Conference on System Sciences. https://doi.org/10.1109/HICSS.2016.623

\section{Copyrights}

Copyright for this article is retained by the author(s), with first publication rights granted to the journal.

This is an open-access article distributed under the terms and conditions of the Creative Commons Attribution license (http://creativecommons.org/licenses/by/4.0/). 